\title{
Religion, politics and the dilemma of modernising Ethiopia
}

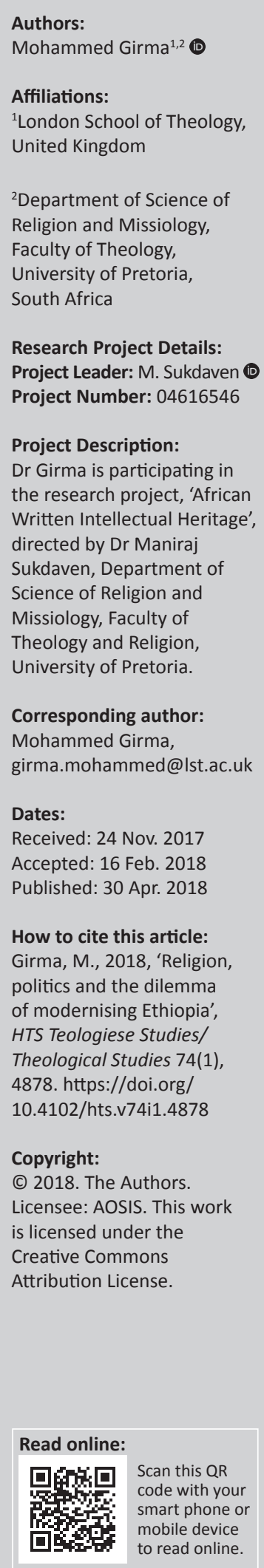

Ethiopia is an old society often confronted with new ideas and foreign values. As a result, social changes and modernisation were important contentious points especially in the late 19th and early 20th centuries. Some wanted change and progress at the expense of indigenous values, specifically cultural and political independence, while others opted for a more cautious approach. Inasmuch as Ethiopia's context was one in which the church and the state were accustomed to seeing themselves as two sides of the same coin, the discourse of modernisation had both a political and religious flavour to it. This article therefore aims to examine the volatile dynamics between religion (especially the Protestant churches of the 'southern peripheries') and the Marxist regime in modernising Ethiopia. Specifically, the article intends to explore how state-church relations transformed social thinking in Ethiopia. I begin by sketching the historical background and proceed to unravel the dilemma of modernisation. In the final part, I discuss how Protestantism contributed to modernising three aspects of social structure: the understanding of the human person, state-church relations and social organisation.

\section{Introduction}

Let me start with a brief sketch of the historical setting. Ethiopia is one of the ancient nations of Africa, with long political and ecclesiastical traditions. The country was governed for over a millennium and a half by Christian monarchs of northern descent. The rulers, for the most part, claimed patrilineal descent from the biblical King Solomon and the Queen of Sheba. The Ethiopian Orthodox Church (EOC) was a crucial part of the system since its introduction in the 4th century. In 1974, a Marxist regime known as the Dergue brought an end to the feudal system and took power after overthrowing the last Solomonic monarch, Haile Selassie. Claiming that religion was the reason for Ethiopian 'backwardness', this regime created an environment that was hostile to religion. In 1991, the Marxist regime was defeated by an ethno-federalist group - the Ethiopian People's Revolutionary Democratic Front - which brought with it a political system that was based on linguistic and ethnic differences. The new political establishment introduced a policy of religions in the public arena where all religious groups could freely practise their faith.

Ethiopia has one of the most indigenised and change-resistant churches - the EOC. This church is a descendent of the Alexandrian tradition, even though along the way it managed to develop its own unique characteristics. As a powerful institution that, from early on, was promoted to the status of state religion, the EOC's worldview permeated the political, social and cultural fabric of the nation (Binns 2016). The theology and philosophy of the church take a cue from Greek Platonic dualism, which manifests itself in a local version of the 'wax and gold tradition' - a philosophy that favours spirituality and asceticism over seeking material gain (Girma 2012). The Alexandrian Church, which embraced Platonic philosophy as a conceptual tool to formulate its theology, was the mother church of the EOC. This connection was deepened not only by the fact that the Abun [the head of the church] was directly sent from Alexandria for almost 15 centuries, but also by the translation of Greek literature of both theological and philosophical nature into Ge'ez (Ference 1985). The most notable of such translations were Angara Falasfa (the book that includes the sayings of Greek philosophers including Socrates, Aristotle and Plato), The Fisalgwos [Physiologue], The Book of Wise Philosophers and The Life and Maxism of Skedens, all having some Greek roots (Makumba 2007). From among these Angara Falasfa, needless to say, is one of the most important texts taught in Ye Abenet Timhert Bet (formerly known as Ye KoloTemhert-Bet) - traditional church schools. Note that Ye Abenet Timhert Bet is where Ethiopian literary experts, philosophers and theologians are trained and nurtured.

One of the ramifications of the impact of dualistic philosophy is that the spiritual is preferred over the material order. Spiritual holidays in which the believers are supposed to abstain from work 
(in a sense of engaging material reality) are multiplied. Those who violate the teaching of the church risk spiritual sanctions as well as social excommunication. Furthermore, the church provided theological justifications for a monarchical political culture (Abbink 2011). New ideas were frustrated and changes were stifled by both ecclesiastical and political forces. Overburdened by the past, both the church and state were unable to join the global metanarrative of modernisation (Tareke 1991). It was in this context that Protestant churches started to find their way to Ethiopia.

Western missionaries began knocking on the Ethiopian door from the dawn of the 17th century. Notably, Peter Heyling, a Lutheran German missionary, arrived in Ethiopia in 1633. However, his desire to reform the EOC was effectively muffled. Slowly but surely, Scandinavian missionaries - such as the Swedish Evangelical Missions, which began in 1866 started to enter Ethiopia. The then-Sudan Interior Mission, now known as Serving in Missions, came to Ethiopia in 1928. Later on, it was from these missionary movements that two prominent Protestant churches emerged - the Ethiopian Evangelical Church Mekane Yesus in 1959 and Qale Heywet in 1971. Denominationally, the former is an affiliate of the World Lutheran Federation while the latter has a Baptist accent with a decidedly Ethiopian colour.

Interestingly, missionaries began to come to Ethiopia during a time in which political leaders were showing more openness to modernisation. The constructive outcome of modernisation in the West tempted Ethiopian leaders to apply aspects of it on their soil. For instance, Zedingle and Suseneyos, between 1604 and 1632, showed interest in the European legal system, firearms and military discipline (Crummey 1998). The nation did not have a local educated force to undertake the arduous task of realising it; neither did the emperors have a strong link with Western powers. The only available agents of modernisation at their disposal were Protestant missionaries with some exceptions from the Catholic side as well. Nevertheless, the main intention of missionaries was not modernising the Ethiopian legal system, military or firearms. Indeed, missionary organisations were probably the last place to seek support to modernise military and legal systems although it would be naïve to dismiss the possibility that some missionaries did have legal and military training. Their principal intention, however, was to reform the church that they felt was stuck in the past. The subtle political purpose of the attempted reform was grooming Ethiopia as an ally to the West against advancing Islam in the neighbouring countries. They thought, therefore, this would be achieved by reconfiguring the EOC's theological and philosophical stance and through re-evangelisation (Eshete 2009).

On the other hand, Ethiopian leaders were wary of both the cultural and political ramifications of reforming the EOC or introducing another form of Christianity. This was especially the case in the religious and political stronghold of the northern part of the country. For the political establishment, the EOC was an important ally that used to provide the state with theological justifications. As Tibebe aptly summarised it, the EOC was 'a religion that embraces culture, politics, flag, identity and nationalism, all put in one package' (ibid). Therefore, the church being exposed to be 'reformed' using foreign elements was tantamount to endangering almost everything about Ethiopian identity. For missionaries, on the other hand, it was clear from their own history that reformation comes before modernisation.

One can surmise from this, therefore, that the modernisation undercurrents between the Protestant Church and the state can be characterised by tension between cultural conservatism and socio-economic betterment. While on the one hand stubbornly - at times for good reasons - defending Ethiopian culture, values and the religion of the EOC, Ethiopian emperors were keen on modernisation. On the other hand, though their primary purpose for coming to Ethiopia was not to repeat the Western scientific success story in an African land, Protestant missionaries from the West had no option but to revise their direct evangelistic and reformist approach to Ethiopia. These conflicting interests - the urgent need for modernisation and protecting the national identity - led Emperor Haile Selassie to issue a decree in 1947. His approach on the decree was to divide Ethiopia into two: closed areas and open areas. Closed areas were the Ethiopian church areas', where missionaries were prohibited from operating, whereas the open areas were in south-eastern Ethiopia where missionaries were allowed to teach their own version of Christianity (Binns 2016). Although this brought the effort of reforming the EOC to an end, it opened up a new frontier.

Western missionaries were diverted from the northern stronghold of the EOC to the southern peripheries of Ethiopia, because these were considered 'pagan' and 'uncivilised'. Western missionaries were welcomed with less suspicion and more enthusiasm on the new frontier. Moreover, they amassed converts to Protestantism from the EOC as well as traditional religions. These 'peripheries' are arguably still dominated by Protestantism.

\section{Modernisation: An Ethiopian dilemma}

In the overall discourse of modernisation, Ethiopia stands on ambivalent ground. This partially has to do with the way modernisation is defined. In the late 1960s, Cyril Black, whose work was praised by some as a 'more graduated appraisal of modernisation', ranked Ethiopia fifth on his scale of seven patterns of modernisation - above all African countries and on equal footing with Japan, Russia, China, Iran, Turkey and so on (Black 1967). This ranking might raise some eyebrows. The reason for perplexity is that the recent history of Ethiopia is known for two things: poverty and a defensive attitude towards the influx of new ideas. However, qualifying his analysis, Black argued:

What these societies have in common is ... that their traditional governments were sufficiently effective, because of long experience with centralized bureaucratic government, to enable them to resist direct and comprehensive foreign rule for a prolonged period in modern times. (pp. 119-120) 
Added to this were its own unique architecture, writing system and social organisations. However, despite Black's optimist exposé, it is apparent that the progress of modernisation was aborted at some stage. What was the reason for aborted modernisation? Where is the starting point that begins to unleash the potential of modernisation, of which signs were shown in the past? Such questions seem to shed a light on the apparent tension between cultural and religious conservatism, on the one hand, and the need for progress, on the other.

To shed more light on the problems involved in modernising Ethiopia, let me discuss the approaches of Afework Gebre Yesus and Gebre-Hiwot Baykedagn - early 20th-century Ethiopian intellectuals. As committed nationalists, both wanted a version of modernisation that would not upset the Ethiopian way of life. In the meantime, both had the concern that Ethiopia might not find the resources for modernisation within itself. The problem both faced was this: How is it possible to modernise Ethiopia through external resources while keeping Ethiopian religious, cultural and social values?

An Italian- and Swiss-educated linguist who served Haile Selassie's regime as a diplomat, Afework was clearly frustrated by Ethiopia's 'backwardness'. Even though he was an ardent admirer of Ethiopian history and values, he believed the ruling class was not able to deliver the necessary reform to put Ethiopia back on track. He put his faith in the civilising mission of colonisers and pushed for forging a strong political alliance with Italy, which he regarded as modern and thus highly advanced. Yet he was aware of the fact that the principal intention behind the Italian occupation was not restoring Ethiopia back to its glory. Still, he thought modernisation was worth such a risky gamble. According to Afework, for modernisation to succeed and bring about an end to economic deprivation, Ethiopians had to be willing to temporarily sacrifice their pride in their cultural and political independence (Gebreyesus 1964). This vision was captured in his novel, Tobbya. The novel is about a foreign king who falls in love with a girl, Tobbya. The king in this novel is powerful, so powerful that people tremble at the news of his coming and no weapon can overpower him. However, Tobbya has secret weapons to tame the powerful king: love and divine covenant. As a result, the king becomes a Christian (1964).

The plot of this novel is similar to the one in Kibre Negest a book that integrated the biblical story of King Solomon and the Queen of Sheba into Ethiopian political narrative. Afework maintained through this novel that Ethiopia had the capacity to 'seduce, change and absorb' and transform the colonising power into a friendly modernising ally (Kebede 1999). He envisaged two ways in which foreign modernising resources could be domesticated.

The first advantage lay in the very nature of modernity itself. As Bahru aptly interpreted:

if Italy took over Ethiopia, civilised it and made it prosperous, the day will then come when the civilised Ethiopians, having become civilised, strong and prosperous, will free themselves from Italy, just as the United States did with England. (Zewde 2002, p. 56)

The underlying philosophical makeup of this move is unorthodox and intriguing in that it is a strategy of gaining by losing. Modernisation brings about a state of affairs by which people would become enlightened. In a typical American fashion, he counted on the Enlightenment to bring about not only prosperity but also independence from foreign power. This, in his conviction, would play in favour of Ethiopians in terms of restoring Ethiopia to its glorious past. In his understanding, modernism by its very nature was a package of liberty and prosperity, and therefore it did not sit well with repression.

Secondly, Afework reminded his readers of the fact that Ethiopia had a spiritual secret weapon: a divine covenant. He went on to construct this ideological formula from a deliberate allegorisation of the myth of the Queen of Sheba and King Solomon to explain the possible outworking of the EthioItalian relationship. Nowhere is this more illuminating than in Kebede's observation of Afework's poem in his novel, Tobbya (Ethiopia):

Just as King Solomon was seduced by the beauty of Makeda, as the result of which Ethiopia became the elect of God, Europeans might too be bound for the same purpose of promoting Ethiopia. In this sense, Tobbya is a new, modernised version of Kebre Negest. In the same manner that Ethiopia became the heir to Judaism and the guardian of Christianity, it will make the best of Western might and technology, provided it welcomes the West and uses its God-given gift to tame the mighty invaders. (Kebede 1999, p. 284)

His approach was risky. In fact, he was accused of committing a treasonous act. However, Afework's approach and underlying assumptions were hermeneutically shrewd. I contend his interpretation of Ethiopian culture and political context was warranted. The source of Ethiopian backwardness was a lack of educated and skilled force. Ethiopia's inability to join the global narrative of modernisation laid bare the fact that the pride of political and cultural independence was hollow. There is merit, as well, in the way he understood the European powers. The reason is that this was not a time when a European country would lend a helping hand to an African nation. In fact, during his time Europeans were racing against each other to exploit as many resources as possible from hapless African countries.

Therefore, firstly, he suggested that welcoming the Europeans would facilitate a learning opportunity for Ethiopia to tackle economic stagnation. Nevertheless, in a typically appealing manner to the conservative elites, he suggested that foreign occupation should be approached with serious scrutiny. He then offered suspicion and domestication as techniques of exorcising the unwanted elements of Western values while 'Ethiopianising' the functional part of foreign inventions. Secondly, after carefully indicating the pros and cons of the situation surrounding modernisation, he (re-)established 
Ethiopia as a nation of the covenant and guardian of Christianity. It was important to maintain this, because Ethiopian covenant thinking was a popular belief that Ethiopia would experience divine blessings because of the inherited Solomonic bloodline, hosting the Ark of the Covenant and accepting Christianity. This narrative was originally propelled by Kibre Negest - a book written by an anonymous author in the 14th century - and is widely held by Ethiopians to this day. Afework then deployed a sexualised symbolisation of the Ethio-Western relationship as a love affair between a foreign king and a local girl. In the same way that the power of the girl lies in her religiosity, Ethiopia's dependence on the divine covenant is a source of victory.

This deliberate allegorisation seems to have had two purposes. First, it reaffirmed that the covenant - the popular belief that Ethiopia has a special promise from God - as a pillar of Ethiopian identity, was sacrosanct and nonnegotiable. Ideally, Ethiopian exceptionalism was not something to trade for material gain. Secondly, joining the global metanarrative of modernisation was crucial in terms of averting 'backwardness'. Instead of polarising Ethiopians between the two seemingly irreconcilable thoughts, Afework chose to take the arduous task of showing that covenant thinking and modernisation were not mutually incompatible. Simply put, the covenant presupposed the greatness of Ethiopia and modernisation and intellectual advancement were crucial tools of realising this 'greatness'.

Now the question is: What about the colonial agenda of dominating and exploiting Ethiopia? Afework contended that the nature of modernisation was intrinsically incompatible with domination. This is because being modernised means being empowered. Nevertheless, despite its promise of reversing backwardness, Afework seemed to understand that using the Ethio-Italian colonial relationship for the purpose of modernisation would be a treacherous process. Even so, he strongly believed that such a risk could be mitigated by the power of Mahteb - a piece of fibre (cloth) worn by EOC believers as a symbol of the covenant. In other words, his contention seems to be that the covenant should not come as a barrier between Ethiopian identity and modernisation. It should rather be considered a spiritual power by which Ethiopia could subjugate the invaders and domesticate their intellectual resources.

Understandably, Afework's theory of modernisation generated mixed reactions. Some accused him of crossing the 'threshold of treason' for intending to welcome the European invaders. Others considered him as patriotic as the people who fought against the Italian occupation and the only difference was that he applied a different (and riskier) tactic.

To avoid the danger of flirting with colonial powers, some Ethiopian intellectuals of the early 20th century tried to fashion Ethiopian modernisation after another advanced country - Japan. The most famous of these 'Japanisers' was Gebre-Hiwot Baykedagn, a German-educated diplomat praised as the most celebrated of the early 20th century
Ethiopian intellectuals' (Zewde 2002). Dismayed by devastating 'backwardness', Gebre-Hiwot also contended that modernisation was the only means of salvation for Ethiopia (Baykedagne 1993). His pattern for modernisation was Japan, a country that managed to modernise itself without upsetting its traditional roots (Beletou \& Bureau 1993). Like Afework, Gebre-Hiwot, while eager to preserve Ethiopian identity, was also critical of Ethiopian culture, which, from his point of view, had stifled change and progress. Among other things, he pointed his finger at cultural values that he thought had promoted war (to protect the nation of the covenant) above knowledge, reflection and work; 'archaic' beliefs and customs that successfully prevented modern education and social reform and conservatism of the nobility and clergy (1993). By 'values that promote war above knowledge', Gebre-Hiwot alluded to the successful campaign of Ethiopian political leaders to mobilise ordinary folks to repel the Italian occupying power. The same values that stood for Ethiopian exceptionalism had failed miserably to mobilise its people to bringing about economic and social betterment. Instead, it romanticised war in the name of protecting the land of the covenant.

But by what approach did Gebre-Hiwot propose to replace what he saw as an outdated 'conservatism' with fluid progress? Education, as Messay points out, was 'the keynote of his program of reform' (Kebede 1999). Starting the reform with education basically aimed at producing elites who were focused on the tasks of the state (1999). Interestingly, instead of top-down, he focused on bottom-up reform. Education, he argued, should not be singularly directed to the ecclesiastical and political elites. Instead, students from the working class should be equipped to enable them to form a new elite group with grassroots sensibility. Part of the reason seems to be that he was convinced that nobility and clergy, at the top of the status pyramid, were helplessly archaic. It was thus difficult to divorce them from the old and damaging political philosophy backed by theological dogma.

Gebre-Hiwot then moved on to proposing a form of governance that would accelerate the Ethiopian modernisation process: '[T]he sort of ruler Ethiopia needs', Gebre-Hiwot argued, 'was a man of order, energy, intellect [...] who is both a friend of Progress and Absolutism' (Caulk 1978). At face value, he may have seemed to opt for autocratic governance, which seems at odds with the modernising effort. However, Gebre-Hiwot was appealing to the Japanese model of modernisation - a kind of modernisation that delivered reform and economic benefit without upsetting the incumbent system. Therefore, the odd combination of absolutism and progress seemed crucial in his proposed program. Namely, he saw the value in absolutism in terms of applying a placid nudge to wake up a society that apparently was hibernating. Progress, Gebre-Hiwot thought, would help society to move on from cultural comfort and excessive spiritualism, which he considered was putting the nation in danger of 'perishing', and perceiving reality in a new way would enhance the comprehensive development of the nation. 
It is clear that the argument for modernisation as postulated by Afework and Gibre-Hiwot was ambitious as well as problematic. First, Afework's suggestion that temporary colonisation by Italy might bring about the much-needed social and economic reform was risky if not outright dangerous. The consequences of political and military occupation would have been detrimental to Ethiopian society. This is because the 'civilising mission' of colonists would not have worked, precisely because their real intentions were exploitation. Secondly, comparison with the relationship between England as coloniser and the United States as a colony that achieved independence was ill-suited to the Ethiopian situation, because most American and English citizens shared a much more similar value system compared to that of Italy and Ethiopia.

Gibre-Hiwot's proposal to apply the Japanese model had its own pitfalls, especially because he deemed an autocratic government necessary for Ethiopia's modernisation. Government can indeed stimulate and achieve modernisation in the realm of economics and technology. The story of Malaysia and China supports this line argument. Yet this option was equally flawed because a version of modernisation that does not fully account for basic human rights leaves some of the fundamental areas of development unaddressed. Both Afework and Gibre-Hiwot opted to combine modernisation with maintaining cultural identity based on Ethiopian exceptionalism. However, it was evident from their proposals that modernisation could not find its origin within Ethiopian culture and religiosity. In their perception it was something that rather needed to come from the outside. Even though their diagnosis of the Ethiopian problem was plausible, their inability and lack of imagination to come up with a home-grown remedy reduced their dreams of meaningful fulfilment.

From Afework and Gibre-Hiwot's analysis, we can deduce that the real hindrance for modernisation lay within the existing political and religious paradigm. This came with a cultural and religious conundrum needing to be resolved. As a result, they could not overcome the conservative system that was ingrained in Ethiopian cultural identity and yet stifled the efforts to change and frustrated its agents. This was the context in which the Protestant Church was born.

\section{Protestants and social transformation}

In what follows, I aim to demonstrate how Protestantism contributed to the modernisation of three areas in the society: the conception of the human person, the church-state relationship and social organisation.

Philosophical anthropology: In the pre-Protestant period, there were two forms of social association. One was based on kinship and the other on compliant association to the unitary state. These two forms of associations had one unifying characteristic: they had no room for the individual. Religious and cultural differences were viewed as either deviation or deficiency (Doulos 1986). In the Protestant paradigm, however, a human person is perceived as a unique individual; difference (or rather uniqueness) is more tolerated. Individuals can change their perceptions and worldview without subjecting to social backlash. One example is daring to change one's religious commitment (Grenstedt 2000). In a communally tight society, changing religion is a major decision. This is precisely because religion is the deepest commitment, gluing them together through a plethora of practices and rituals. Therefore, the individualisation of religion was a significant change in a culture where religion was thought of as a communal practice, not an individual one.

This starts with the introduction of the notion of 'accepting Jesus Christ as the personal saviour'. This is a major break from the traditional way of understanding the human person, because in both indigenous religions and EOC contexts religious decisions are communal rather than individual. While the EOC tends to understand the human person as a part of the Christian communion, indigenous communities cannot conceive of a person outside the ethnic and religious umbrella. This is because there is hardly any place for the individual in their social philosophy. In fact, in both, individuality is considered a social anomaly often generating excommunication and even persecution. This, for Protestants, is a very crucial departure because their teaching puts a particular emphasis on conversion and personal responsibility. It is considered that faith is a personal matter and so is accountability before God for one's decision. Christ himself is designated as ye gel adagne [personal saviour]. In essence, therefore, a human person in this tradition is considered to be a rational individual who can make his or her own decision with or without the approval of the community. Such an understanding of a human person was a challenge in that it had the potential to upset the social structure and traditional chain of existence.

In the meantime, the Ethiopian Protestant churches experienced exponential growth during the Marxist regime, also known as the Dergue. The Marxist state was aiming at the creation of the 'new socialist man' - a man whose interpersonal feelings were to be replaced by group identification. This ideal 'new man' was strong, wise and subtle in nature with a harmonious body and rhythmic movement and musical voice (Moses 1998). For the Marxists, man's essence was the potential for emancipation and selffulfilment. The outworking of such a conception was that human nature was determined by material conditions of existence. Nevertheless, both traditional society and Marxist philosophy conceived a human person as an inherently communal being, with little space left to experience individuality.

The emergence of Protestantism recalibrated the conception of a human person. Freedom and the will to make a highly important individual decision - specifically, changing one's religion - became a major point of contention. This meant that the social structure as understood in traditional society 
could not be sustained. People were judged by their individual character more than by their ethnic or political allegiance. In fact, because of new understandings of a human person, people who were on the social margins were attracted to Protestant churches, the reason being that it created a space in which they could command equal respect (Yoshida 2009). This was also reflected in gender equality. For example, in pre-Protestant times, it was hardly possible for a head of a clan to sit with women and children in the same meeting, and even less so in church. It was only the advent of Protestantism that made the social hierarchy obsolete and created a more egalitarian understanding of society (Hege 1998). This also resulted in a significant power shift. Merits rather than blood relations became the criteria for climbing the ladder of leadership. Education played an important role in acquiring leadership skills, both in an ecclesiastical as well as a social setting. By creating emergent elite groups, the new understanding of social structure significantly undermined the role of shimagilewoch [traditional elders], dagnas [local kings] and traditional 'prophets'. Instead the role of leadership was taken by progressive youth, incorporating men and women.

Church-state relations: After the downfall of the feudal system, the new Marxist regime did not have a wellarticulated policy towards religion (Larebo 1988). However, it strengthened one major point of departure half-heartedly introduced by the previous political system - the declaration of the separation between the state and the church. Besides losing its status as a state religion, the EOC became the target of political attack for being an integral part of the power structure of the monarchy. While it was once the church with a fascinating history, it was now accused of being the reason for Ethiopia's backwardness (Eshete 2009). In an effort to drain the source of the social stagnation, the moral education offered by the EOC was replaced with the secular philosophy of dialectical materialism.

For Protestant churches, the general posturing of the Marxist regime had some resonance. Because of the anticipatory attitude that Western (missionary) teaching created, 'Protestants saw the revolution as progress toward a distinctly new and hopeful future' (Donham 1986). They disassociated themselves from the previous political system and the church that backed it by providing theological justification to it (Eide 2000). Most importantly, its initial narrative of change and progress captured their imagination, and they saw this as an escape route from the oppressive monarchic system (Belete 2000). The reason is that when the missionaries came to the southern peripheries they approached them with a similar message, albeit their narrative deliberately eschewed the political significance. Namely, they moved to the southern and south-western ethnicities with a message of 'freedom'. The notion of freedom was a reality and metaphor at the same time. It was a reality because, firstly, Protestant missionaries did not force them to deny their identity, culture or way of life (Bakke 1986). Secondly, the immediate context to the message of freedom was the oppressive animist religious practices. However, even though this was presented in a politically neutral manner, the concept of freedom had far-reaching implications as a metaphor. This is because the term 'freedom' by its nature inevitably has a political tinge to it. For example, in ancient Greek 'freedom' means gaining the status of being one's own master after experiencing slavery. Technically, the people in the southern peripheries were not slaves. However, they were not in a position to make critical decisions - such as following the religion of their choice, being involved in the political process or choosing which identity they wanted to have - without political and religious intrusion. So, freedom as a metaphor provided them with a subversive narrative by which they could negotiate their identity and place both in the spiritual and political realms.

Another important metaphor was the notion of dagem lidetbeing 'born-again'. The metaphor of dagim lidet in the Ethiopian context denotes being born into freedom. As Tibebe aptly explains, '... to be a Christian is not something predetermined or a claim made through a family inheritance; rather, it is a definite experience, a conscious and responsible act of the will' (Eshete 2009). Not only did the new way of life stand in sharp contradiction to the previous worldview, it also brought the issue of 'salvation', both in a spiritual and political sense, to the public sphere. Freedom and being born again became a conceptual matrix through which believers filtered elements of religious and political practices. To wit, elements that were alien to this framework would be pushed back by the adherents of the Protestant faith. This stance, then, became a flashpoint between the Protestant churches and the Marxist regime. For example, Eide reported that Gudina Tumsa, a Protestant church leader, saw the gospel of Jesus Christ as God's power to save everyone who believed in it. More importantly, salvation, the way he saw it, was not limited to escaping eternal damnation; it also included liberation from economic and political oppressions. To the fury of the Marxist leaders, Gudina reportedly stood against replacing the eternal dimension of the gospel by any ideology invented by humans, because it was too dear a treasure to be given up (Eide 2000).

His message captured the fact that the Christian struggle by no means was limited to the numinous cosmic struggle between good and evil. It had its feet in the daily social and political experience of believers. This new standing assumed two oppositions: a backlash from the traditional religious system and the Marxist regime that was keen on reconfiguring the socio-political system. The traditional religious system had its own socio-political and economic structure, and failure to comply with religious demands could come at a cost because of the consequences to social harmony. At the very least, it limited the sphere of activity for believers. On the political front, the believers in the southern peripheries had fresh memories of a long history of inter-ethnic tension, slavery and oppression (Donham 1986). Furthermore, there were instances where people in these areas had to undergo Christian baptism at gunpoint (Tolo 1998). The message of freedom that the missionaries brought was appealing to the locals because it was non-violent, and more importantly it 
carried a message of liberty with multiple layers. As Eide pointed out, 'Religious expression ... takes on a meaning within the political realm' (Eide 2000).

In the meantime, paranoid about external and home-grown opposition forces, the state started to interfere with the church. The Protestant churches, as a result of being planted by Western missionaries, were considered to be foreign products. In fact, Addis Zemen, a state-owned newspaper, portrayed the Protestant churches as the schemes of imperialists who intended to derail the revolution and paralyse the minds of the youth by promoting idealistic thoughts (Addis Zemen, 21 May 1978). Subsequently, rooting out alien values associated with foreign influences became a part of political propaganda. This eventually unmasked the real intention of the Marxist regime concerning Protestantism in particular, and religion in general. Another flashpoint was the fact that the Protestant worldview was unwittingly providing a competing idea of modernisation based on the Western Judeo-Christian values. They saw this as a nuisance to their brand of modernisation, which took a cue from the Chinese Cultural Revolution. While the former took religion - specifically Protestant Christianity - as a launching pad, the latter saw religion as an obstacle for Ethiopian progress.

Accordingly, the regime took a stance of rooting out the Protestant faith from Ethiopian soil. However, regardless of repression from the Marxist regime (and the EOC, even though it was functioning from a weakened position), there was no organised response from the Protestant churches. The lack of concerted response, as indicated above, stemmed from lack of political awareness and the absence of articulated positions on the interface of religion and politics. Instead of taking shape into a movement, the opposition was benign and practically oriented. The only person who attempted to mount an open challenge to an increasingly volatile regime was Gudina Tumsa. This was because of a combination of factors. Firstly, according to Tasgara Hirpo, Gudina grew up with people who claimed to have been deprived of religious, cultural and political rights. Secondly, he experienced 'true liberation' when he received the Protestant faith (Tasgara 2005). Thirdly, he studied theology at Luther's Seminary, USA, when the civil rights movement was at its peak. Fourthly, while studying theology, he was exposed to Dietrich Bonhoeffer - a German theologian who stood up to the Nazis and was fascinated by holistic theology. The accumulation of all these experiences coloured his vision of church and society.

Living under the communist regime, he organised several workshops to understand what it means to be a Christian while living under a repressive regime. In the midst of faction and political chaos, he urged the church to maintain a reconciliatory stance. At the peak of the bloody revolution, he organised the Council for Cooperation of Churches in Ethiopia, which included Catholics and the EOC, so they could weave a Christian narrative together to address the political crisis, which was pitting political groups against each other (Eshete 2009). In the end, Gudina paid the ultimate price for trying to come up with an organised response to the state. He was abducted and murdered by the regime.

Yes, the Protestant churches did not have resources (or time) to articulate the interface between state and church, or religion and politics. However, by standing true to their concept of 'rebirth into freedom' and benign resistance, they were able to expose the limits of the state in its interference with religious affairs.

Social structure: Encouraged by the initial anti-conservative political rhetoric of the Marxist regime, the Protestant churches were hopeful that they would have civic roles to play in society. In fact, they supported the regime during the early wave of revolution. They were optimistic about the abolition of the class system, land reform and the newly found egalitarianism. ${ }^{1}$ However, the Marxist regime turned oppressive and violent in forcing its ideology. This, instead of drawing them closer to the national project of the regime, made them construe their own conception of social structure (I will briefly discuss this shortly). As a result, they started to get disillusioned by the regime when early patriotism took a shape of the 'cult of motherland'. As tempting as social reforms were, Christians started to resist choosing the regime's sanction to sing patriotic songs and recite slogans as part of their daily ritual. This is because they thought elevating enat ager [motherland] above God was against their Christian conviction.

Protestant believers had several other reasons for distancing themselves from the regime. Firstly, they thought that the bridge between the regime and themselves was broken when the state was reconfigured in such a way that it could function from an irreligious standpoint. Scientific materialism, the regime espoused, was a new (and ungodly) religion. They started to see the regime as an obstacle to the divine blessing of Ethiopia. Secondly, and more devastatingly, the fact that they were treated as second-class citizens because of their faith created identity disorientation. Then the Protestant churches took on the task of (re-)construing their identity to their podiums. The outcome was the formation of the unwitting notion of semayawi zeginet [heavenly citizenship].

What did the notion of semayawi zeginet constitute? Admittedly, semayawi zeginet was not a notion borne out of careful academic articulation. Obviously, the Marxist regime was far from allowing an academic space for the Protestant churches to reflect on their identity. This conception, however, is based on Pauline teaching (Phlp 3:19). In the Pauline context, Philippi was a Roman colony. While a few of the Philippians had Roman citizenship, most of the believers were subjects rather than citizens. Moreover, the non-citizens had to live as a persecuted minority. Hence, Paul wrote to those who were feeling alienated that their citizenship was in heaven. The parallel between their conditions was unmistakably clear. Protestant believers were given unflattering names - mette [the newcomers, or the aliens] - alluding to the origin of their 1.See the example of the Maale ethnic group in Donham's Revolution and Modernity in Ethiopia. 
faith in the West. Accordingly, they started to see themselves as home-grown aliens because of severe persecution by the regime and cultural marginalisation by other religious groups. The notion of heavenly citizenship was able not only to provide them with a feeling of new hope, but the hope of new heavenly privileges. This citizenship constituted an acceptance of people regardless of ethnicity, social class, gender or economic status, based solely on sharing a common faith. In a context in which their 'earthly citizenship' was under serious doubt, semayawi zeginet was the only concept that could provide the Protestant community with a sense of community (Yoshida 2009).

Now, what was the consequence of the Protestant conception of society? The emergence of semayawi zega as a social concept had spiritual, social and economic ramifications. Spiritually, it provided them with a support system in difficult times, such as an underground network and chain prayer. Believers would find spiritual resources in other denominations when their churches were closed or confiscated. Furthermore, it created a platform to share with and learn from each other. Diminishing denominational lines meant that the churches could focus on what they thought would matter the most: strengthening their unity and 'winning souls' to new citizenship.

Socially, such a conception of citizenship helped the church to overcome ethnic divides. Under heavenly citizenship, a member could be fully embraced within the community regardless of ethnic background or social status. The basic assumption was that heavenly citizenship transcended ethnic and cultural boundaries. Overcoming one's own ethnic biases and joining the new community under a new identity was part of 'rebirth' and freedom. Protestantism seemed to serve as a venue where people from varied cultural and ethnic backgrounds could practise social 'glossolalia' - a language that was diverse, yet intelligible and redeeming.

Economically, the cause of poor peasants gained precedence on the Protestant agenda. It signalled a philosophical shift away from a class-oriented system to more communitarian pietism. Johnny Bakke portrayed this as 'a way of meeting challenges from the Enlightenment without abandoning the faith in the Bible as the word of God' (Bakke 1998). Bakke's interpretation of Protestant motives as a balanced manoeuvre between biblical faith and Enlightenment might be true with regard to missionary work. Doubtless, the general philosophy of Protestant believers was much more akin to Enlightenment ideals than that of EOC believers. Yet Protestant churches in Ethiopia did not have the space or resources to articulate the marriage between the Bible and the Enlightenment. If there was any element of balance between Enlightenment ideas and the biblical message, then this was unwittingly triggered by the intention to meet immediate needs.

Politically, the church developed what could be called a 'politico-phobic' attitude after the persecution. The alleged 'godless' attitude of the Marxist regime made believers perceive any involvement in politics as a betrayal of
Christian faith. This, in turn, made the church create its own island. Protestant churches either went underground, or their activities were largely limited within the four walls of the church. The church insulated itself from engaging in public issues. Even in their relationship to the Marxist regime, as Tibebe rightly portrayed, Protestant churches 'chose the path of suffering, the catacomb road [...]' instead of making 'deep theological reflections on itself and its wider role in the socioeconomic and political environment of Ethiopian society [...]' (Eshete 2009).

\section{Conclusion}

This article set out to investigate how the dynamics between Protestant churches and the Marxist regime transformed Ethiopian social thinking. Special focus was given to the individual, church-state relations and social structure. These churches were born in a complex cultural and political milieu and engaged in a volatile relationship with different ecclesiastic and political agents. They shared some values with each agent but found themselves contradicting some of the central values of the agents. Contradictions were generated amidst the Protestant churches trying to stand outside the shadow of the incumbent political and ecclesiastical system while consolidating their identity and their belief system. Therefore, modernisation was not their top agenda. Neither did they have a well-articulated plan to stand in opposition to the political programmes of the state. However, the new faith and its message of freedom gave them a taste of individuality, the ability to negotiate their place in society and experience the limit of the state interfering with religious affairs, as well as the individual's ability to choose. Therefore, two conclusions can be drawn from the analysis presented in this article. Firstly, Protestant churches made a significant contribution to the modernisation of Ethiopia. However, modernisation itself was borne out of the impact of ideological disruption that Protestant churches unintentionally brought. Secondly, Protestant churches had an unstable relationship with the Marxist regime. Although persecuted by the Marxist regime, Protestant churches ultimately helped the state's effort towards social transformation.

\section{Acknowledgements Competing interests}

The author declares that he or she has no financial or personal relationships which may have inappropriately influenced him or her in writing this article.

\section{References}

Abbink, J., 2011, 'Religion in public spaces: Emerging Muslim-Christian polemics in Ethiopia', African Affairs 110(439), 253-274. https://doi.org/10.1093/afraf/ adr002

Bakke, J., 1986, Christian Ministry: Patterns and function within the Ethiopian Evangelical Church Mekane Yesus, Humanities Press, NJ.

Bakke, J., 1998, 'Models of leadership in Ethiopia: Missionary contribution', in G. Haile \& S. Rubenson (eds.), The missionary factors in Ethiopia: Papers from a Symposium on the Impact of European Missions on Ethiopian Society, Lund University, August 1996, pp. 155-167, Peter Lang, New York.

Baykedagne, G., 1993, L'Empereur Menelik et L'Ethiopie, United Printers, Addis Ababa. 
Belete, G., 2000, Elohe ena Haleluya, KHC Literature, Addis Ababa.

Beletou, K. \& Bureau, J., 1993, L'Empereur Menelik \& I'Ethiopie, Maison des études éthiopiennes, OpenEdition Books, Addis Ababa.

Binns, J., 2016, The Orthodox Church of Ethiopia: A history, IB Tauris, New York.

Black, E.C., 1967, The dynamics of modernization: A study on comparative history, HarperCollins, New York.

Caulk, R., 1978, 'Dependency, Gebre Heywet Baykedan and the birth of Ethiopian Reformism', in R. Hess (ed.), Proceedings of the Fifth International Conference of Ethiopian Studies. Session B, April 13-16, 1978, Chicago, 1979, pp. 569-581, University of Illinois, Chicago, IL.

Crummey, D., 1998, 'Politics of modernization: Protestant and Catholic missionaries in Ethiopia', in G. Haile (ed.), The missionary factor in Ethiopia: Papers from a Symposium on the Impact of European Mission in Ethiopian Society, Lund University August 1996, pp. 85-99, Peter Lang, Berlin.

Donham, D., 1986, 'Old Abyssinia and the New Ethiopian Empire: Themes in social history', in D. Donham \& W. James (eds.), The Southern Marches of Imperial Ethiopia: Essay in history and social anthropology, pp. 3-50, Cambridge University Press, London.

Doulos, M., 1986, 'Christians in Marxist Ethiopia', Religion in Communist Lands 14(2) 134-147. https://doi.org/10.1080/09637498608431248

Eide, O., 2000, Revolution \& religion in Ethiopia: The growth \& persecution of the Mekane Yesus Church, 1974-85, James Currey, Oxford.

Eshete, T., 2009, The evangelical movement in Ethiopia: Resistance and resilience, Baylor University Press, Waco Texas.

Ference, A., 1985, 'Writing and literature in classic Ethiopic (Giiz)', in B.W. Andrzejewisky et al. (eds.), Literature in African languages: Theoretical issues and sample survey, pp.255-300, Cambridge University Press, Cambridge.

Gebreyesus, A., 1964, 'Tobbiya', Ethiopia Observer 8, 242-267.
Girma, M., 2012, Understanding religion and social change in Ethiopia: Towards a hermeneutic of covenant, Palgrave Macmillan, New York.

Grenstedt, S., 2000, 'Ambaricho and Shonkola: From local independent church to evangelical mainstream in Ethiopia', Doctoral dissertation, Uppsala University.

Hege, N., 1998, Beyond our prayers: Anabaptist Church growth in Ethiopia, 19481998, Herald Press, Scottdale, PA.

Kebede, M., 1999, Survival and modernization: Ethiopia's enigmatic present: A philosophical discourse, Red Sea Press, Asmara.

Larebo, H.M., 1988, 'The Ethiopian Orthodox Church and politics in the twentieth century: Part II', Northeast African Studies 10, 1-23.

Makumba, M., 2007, An introduction to African philosophy, Paulines Publication Africa, Nairobi.

Moses, G.L., 1998, The image of man: The creation of modern masculinity, Oxford University Press, New York.

Tareke, G., 1991, Ethiopia: Power and protest: Peasant revolts in the twentieth century, Cambridge University Press, Cambridge.

Tasgara, H., 2005, 'The cost of discipleship: The story of Gudina Tumsa', Word \& World 25(2), 159-171.

Tolo, A., 1998, Sidama and Ethiopia: The emergence of the Mekane Yesus Church, Studia Mssionalia, Uppsala.

Yoshida, S., 2009, 'Why did the Manjo convert to protestant? Social discrimination and coexistence in Kafa, Southwest Ethiopia', in S. Ege, H. Aspen, B. Teferra \& S. Bekele (eds.), Proceedings of the 16th International Conference of Ethiopian Studies, pp. 299-309, Society of Ethiopian Studies, Trondheim.

Zewde, B., 2002, A history of modern Ethiopia, 1855-1991, Ohio University Press, Athens, $\mathrm{OH}$. 